\title{
Development of Sustainability Reporting Guidelines for Indonesian Local Government
}

\author{
A.Sofia, B. S.Purnomo, R. N. N.Apandi, R. D.Yuniarti \\ Accounting Department, Universitas Pendidikan Indonesia \\ Bandung, INDONESIA \\ alfira.sofia@upi.edu
}

\begin{abstract}
Organizations that concerned on profit without responsiveness on environmental and social influences created from business operations, consequently cannot hold its life in the long term (sustainable). The government as a public sector organization is obliged to pay attention to the three pillars of sustainability, namely: 1) Earth (planet) along with all its contents, plants and animals - Ecosystem; 2) Human (People); and 3) Economics (Profit) or so-called triple bottom line. This research was conducted to identify the indicators of sustainability reporting disclosure associated with the local government economic, environmental and social, as well as determine the important factors that should be disclosed by local governments in their sustainability reports. This article is part of the first phase of the research conducted in producing guidelines for a complete and comprehensive disclosure to the City/County in Indonesia. As a preliminary study, data collection method used in this study consists of two sections, namely: 1) literature review and benchmarking; 2) survey methods. Data from first method were collected and analyzed to find appropriate factors for Indonesia local government context. While the survey methods are used to gather perceptions from academics and practitioners, and to have knowledge of the sustainability report. This research used confirmatory factor analysis to determine significant indicators simultaneously test the reliability and validity of the proposed model. The results of this study showed that the main factors of sustainability report disclosure model consist of Environmental, Economic, and Social. Environmental factors disclosure contains 21 indicators, economic factors consists of six disclosure indicators, whereas social factors containing three dimensions namely labor (8 indicators), society (12 indicators), and human rights (10 indicators).
\end{abstract}

Keywords-sustainability reporting, triple bottom line, local government

\section{INTRODUCTION}

The growing business competition has forced economic actors to maintain the viability of their business (going concern). Profit is one of the indicators of the organization's success in maintaining its survival; the greater the level of income generated the more organization is considered as a successful organization. In a public sector organization, such as the government, which is not profit-oriented, social and environmental responsibilities should be the main focus because social and environmental impacts caused by the development of technology and industry has led to some destructions on the earth [1], [2]. Every organization, both profit and nonprofit oriented, should be able to recognize, manage and change the paradigm in relation to environmental and social issue. A sustainable development needs to be done because the increasing numbers in human population, water use, $\mathrm{CO}_{2}$ concentration, number of cars, use of non-organic fertilizers, deforestation, excessive paper consumption and exploitation of fishery [1].

West Java is one of the most populous provinces and the highest intensity of vehicle users in Indonesia. Comprising 26 cities and regencies, West Java is a province with a population of 39,140,812 inhabitants (BPS Census 2010). Therefore, as an initial research, this study uses the province of West Java as a pilot survey that is expected to be developed further so that it can be applied more widely to all cities and regencies in Indonesia on advanced research stages.

Local government as the executive branch, especially in the era of regional autonomy, has a relatively large authority in their respective areas. In terms of its functions, together with DPRD in making local regulations, each local government must also make rules relating to environmental and social issues. In order to make the regulation effective, local governments should be able to apply the rules internally before demanding citizens to comply with such rules. Participation of local government in an effort to reduce the footprint that is the excessive use of $\mathrm{CO}_{2}$ is indispensable through the creation of programs that support it and applied in the Local Government and the population in the working area of local government. Efforts are being made at the local level include walking culture, by providing a bicycle in specific areas to reduce the footprint. The local government introduces savings on paper use or transfer all documents into electronic forms. The use of $3 \mathrm{R}$ concept (Reduce, Recycle, and Reuse) must be applied in a government office environment for example by saving envelope that may be used repeatedly or recycling of the paper. Many more activities in government agencies that need to be regulated in pursuit of social and environmental performance. [2]

Local Government Agencies (SKPD) within the Local Government relating to core job description in environment and social sector should be optimized to prepare a Sustainability Report (SR), which provides information to all stakeholders about efforts made by local governments in promoting the principle of 3P (Planet, People and Profit) [1]. 
The awareness to manage and change the view of the social environment should start from the local government employees and government offices within the region itself. Government of West Java province, in an effort to encourage the implementation of optimized sustainability report, give an award to the City/Regency Local Government that are able to provide the most complete disclosure of Sustainability Report.

Evolution occurs in the preparation of an organization's report. In $1850 \mathrm{~s}$, organization officials thought that the organization were enough to prepare financial statements only as a form of accountability measure, but nowadays even public sector organizations are required to prepare a sustainability report that is integrated with the financial statements. Those two forms of accountabilities in 2010 known as Integrated Reporting. It is a report on the Financial, Economic, Environment, Social and Governance [3].

This article will answer the aim of the study, that is to identify the indicators of sustainability reporting disclosure by local government related to economic, environmental and social, as well as determine the important factors that should be disclosed by the local government on their sustainability reports. This article presents the research findings that are part of the first phase of the research that has been conducted by researchers in order to identify and prepare for the implementation of sustainability reporting on local government in Indonesia. The presentation begins by theoretical review on underlying the need for disclosure of sustainability reporting in the government, and the current condition of the related research. Afterwards, the article describes the research methodology used to answer the research problems. Results of the study are described in the form of descriptions, tables, and figures that contain the results of the analysis and the results of data processing that have been collected. At the end, there are conclusions and further research that is planned as a series of this study.

\section{THEORETICAL REVIEW}

Previous research [5][6][7] was mentioned that currently various companies, mostly multinational companies engaged in the extractive sector, genetic sector, manufacturing, and service sectors in the broad sense, have announced a corporate governance report as well as their impact on economic, social, and environmental in a sustainability report. Reference [8], it is explained that many of the industry and service companies are now implementing environmental accounting. The goal is to improve the efficiency of environmental management by assessing the environmental activities from the standpoint of costs (environmental costs) and benefits or effects (economic benefits). Environmental accounting is applied by various companies to produce a quantitative assessment of the costs and impacts of environmental protection. In the internal functions it is expected that environmental accounting functions as a business management tool that can be used by managers when dealing with business units [8]. External function is a function that is related to aspects of financial reporting. In this function, an important factor to consider is the company disclosure of the results of environmental conservation activities in the form of accounting data.
Sustainability report as described above refers to a business process performed in the private sector. This report adopts the concept of the private sector which is applied in the operating process in the public sector. It is growing in line with the concept of new public management. This concept first appeared in Europe as a result of dissatisfaction with the management of the public sector which was considered very wasteful [9]. Therefore, by using the principle of the private sector, a frame of reference was created regarding the sustainability report for regional governments. Sustainability reports for local governments is the information given to the public about the important aspects of local government activity related to economic, social and environment activities in a comprehensive manner. The purpose of this report is to achieve sustainability development, wherein development undertaken by the government in meeting the needs of public goods and services cannot be separated from efforts to balance the natural and social communities.

TABLE I. SAMPLE OF IMPLEMENTATION OF SUSTAINABILITY REPORT IN SEVERAL COUNTRIES

\begin{tabular}{|c|c|}
\hline Country & Current Achievement \\
\hline Australia & $\begin{array}{l}\text { The overall level of disclosures was low. There are three } \\
\text { possible explanations for this: } \\
\text { - the fact that the GRI Sustainability Reporting Guidelines and } \\
\text { the sector supplements are voluntary and there is no legal or } \\
\text { statutory obligation for public sector agencies to adhere to } \\
\text { these, } \\
\text { - the reporting of various sustainability indicators is a relatively } \\
\text { new phenomenon still in its infancy for the public sector and, } \\
\text { - in relation to the second point, council officers require } \\
\text { increased resources and specifically, training and } \\
\text { education in order to fulfil the requirements of the GRI } \\
\text { guidelines. }\end{array}$ \\
\hline Scotland & $\begin{array}{l}\text { The purpose of the reporting is to improve performance } \\
\text { management in relation to sustainability, through greater } \\
\text { accountability and transparency. }\end{array}$ \\
\hline Italy & $\begin{array}{l}\text { These programs are characterized by some of the following } \\
\text { elements, taken from a local agenda experience in Italy (Bollini, } \\
\text { 2000): } \\
\text { - equal opportunity in society and social integration - equal } \\
\text { - access to all fundamental services like education, } \\
\text { employment, } \\
\text { - energy, health care, housing, job training and } \\
\text { - transport; } \\
\text { - Local government/ decentralization/ democratic practices- } \\
\text { common access and participation in local planning and } \\
\text { decision-making; } \\
\text { - Relationships between local and global issues - satisfy local } \\
\text { needs, from production to consumption and waste } \\
\text { management, and make them more sustainable; } \\
\text { - Local economy - combine objectives and local needs with } \\
\text { available jobs and other services in order to minimize } \\
\text { damage to natural resources and the environment; } \\
\text { - Environmental protection - decrease depletion of land and } \\
\text { natural resources, control waste accumulation and toxic } \\
\text { emissions and increase biodiversity; } \\
\text { - Cultural heritage environmental quality in towns-protect, } \\
\text { conserve and restore works of historical, cultural, } \\
\text { architectural importance including buildings, monuments } \\
\text { and local cultural events; protect the aesthetic and functional } \\
\text { qualities of urban space and buildings. }\end{array}$ \\
\hline
\end{tabular}




\section{RESEARCH METHODOLOGY}

Objects of this research are factors and indicators in the implementation of Sustainability Report (SR) for Cities/Regencies in West Java. Results of this study is in the form of a draft guide for the preparation of Sustainability Report. Data processing was conducted through the management of all data that have been collected from a variety of methods that were used, namely:

\section{A. Documentation Study}

Documentation study in terms of existing theories relating to the sustainability report was conducted to obtain the theoretical foundation on how to build and implement a sustainability report in local government. The documents that were used include the guideline for the implementation of SR for companies compiled by the Global Reporting Initiative (GRI), an annual sustainability report from Scotland.

\section{B. Questionnaire}

To obtain primary data for this study, questionnaires were distributed to respondents. Measurement scale used is Likert scale. Respondents are academics and practitioners from the fields relevant studies were required to give their perception/opinion on the level of importance of these indicators. Statements used in the questionnaire were developed from an analysis of the results of the documentation study. Furthermore, the data were processed by confirmatory factor analysis, which is one of the multivariate analysis that was designed to investigate the nature of the relationship between variables in a particular device that basically shows a pattern of a particular relationship [10][11].

\section{RESEARCH FINDING}

\section{A. Identification of variables, dimensions, and indicators through Literature Review and Benchmarking}

Boston College Center for Corporate Citizenship and Ernst \& Young conducted a survey in 2013, the result is as follows:

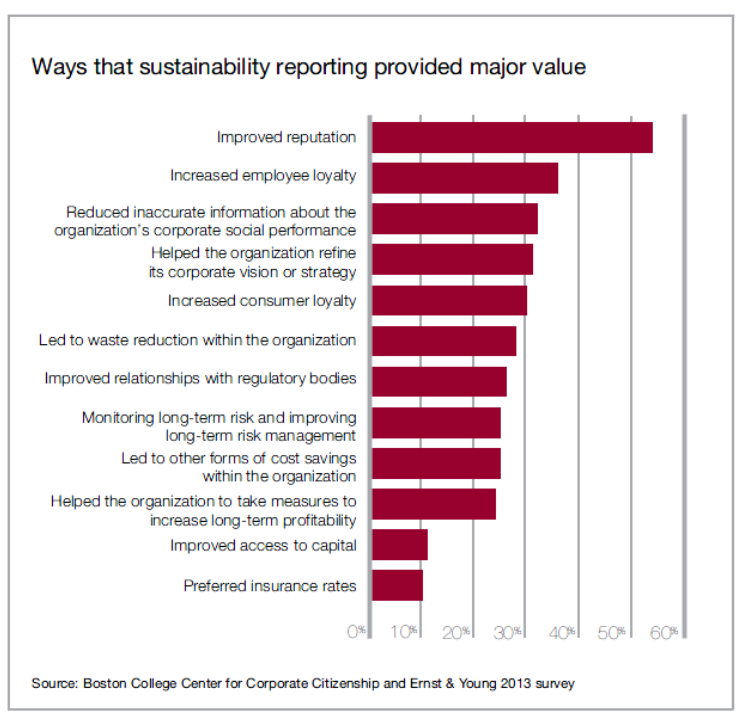

Fig. 1. Major values that arise from the implementation of sustainability reporting

From the figure above, it can be observed that sustainability reporting can provide major value through: Financial performance, Access to Capital, Innovation, waste reduction and efficiency, Risk management, Reputation and consumer trust, Employee loyalty and recruitment, and Social benefits. Based on the collection of documents, especially those from the Global Reporting Initiative (GRI) and benchmarking against best practice in some countries that have conducted a pilot project for sustainability reporting implementation and analyzed by the research team and the results are described as follows: 
TABLE II. VARIABLES FROM PROPOSED MODEL

\begin{tabular}{|c|c|c|c|c|}
\hline \multirow[b]{2}{*}{ Variable } & \multicolumn{2}{|r|}{ Proposed } & \multicolumn{2}{|r|}{ Scottish Government } \\
\hline & Dimension & Indicator & Dimension & Indicator \\
\hline \multirow[t]{5}{*}{ Environment } & $\begin{array}{l}\text { Consumable } \\
\text { Supplies }\end{array}$ & $\begin{array}{l}\text { L1 Consumable supplies (volume/quantity) } \\
\text { L2 Percentage of consumable supplies that can be recycled }\end{array}$ & & \\
\hline & Energy Source & $\begin{array}{l}\text { L3 The proportion of direct energy used as a primary energy source } \\
\text { L4 The proportion of indirect energy used as a primary energy source } \\
\text { L5 Efforts to use alternative energy sources } \\
\text { L6 Efforts to save energy and use of environmentally friendly energy sources }\end{array}$ & ENERGY USE & $\begin{array}{l}\text { Gross emissions by source: } \\
\text { Electricity (renewable) } \\
\text { Electricity (non-renewable) } \\
\text { Gas } \\
\text { Other fuels for buildings } \\
\text { Marine operations } \\
\text { Energy consumption by type: } \\
\text { Electricity (renewable) } \\
\text { Electricity (non-renewable) } \\
\text { Gas } \\
\text { Other fuels for buildings } \\
\text { Marine operations } \\
\text { Expenditure by type: } \\
\text { Electricity } \\
\text { Gas } \\
\text { Other fuels for buildings } \\
\text { Marine operations } \\
\text { CRC payments }\end{array}$ \\
\hline & Water Source & $\begin{array}{l}\text { L7 Source and volume of water used } \\
\text { L8 Impact of the utilization of water resources } \\
\text { L9 Number and percentage of water recycled and reused }\end{array}$ & WATER & $\begin{array}{l}\text { Water volume: } \\
\text { Supply } \\
\text { Disposal } \\
\text { Expenditure by type: } \\
\text { Supply } \\
\text { Disposal }\end{array}$ \\
\hline & Biodiversity & $\begin{array}{l}\text { L10 Total land area of offices and other facilities on land with improper designation } \\
\text { L11 Impact on nature and biodiversity arising from the construction of offices and } \\
\text { other facilities } \\
\text { L12 Strategy, activities carried out and plan ahead to minimize the impact on nature } \\
\text { and biodiversity } \\
\text { L13 Efforts to protect and develop biodiversity in offices and other facilities }\end{array}$ & BIODIVERSITY & \\
\hline & Waste & $\begin{array}{l}\text { L14 Use of environmentally friendly work equipment } \\
\text { L15 Maintenance of vehicles and other energy generators to minimize exhaust } \\
\text { emissions (NO, SO and other chemical elements that may degrade air quality) } \\
\text { L16 Efforts to minimize garbage and other solid waste } \\
\text { L17 Waste management activities and other solid waste } \\
\text { L18 Efforts to minimize the waste water } \\
\text { L19 Wastewater treatment activities }\end{array}$ & $\begin{array}{l}\text { GREEN HOUSE } \\
\text { GAS EMISSIONS } \\
\text { WASTE }\end{array}$ & $\begin{array}{l}\text { Gross emissions by source: } \\
\text { Recycled or reused } \\
\text { Hazardous } \\
\text { Energy from waste } \\
\text { Landfilled } \\
\text { Waste arisings by disposal route: } \\
\text { Recycled or reused } \\
\text { Hazardous } \\
\text { Energy from waste } \\
\text { Landfilled } \\
\text { Expenditure }\end{array}$ \\
\hline
\end{tabular}




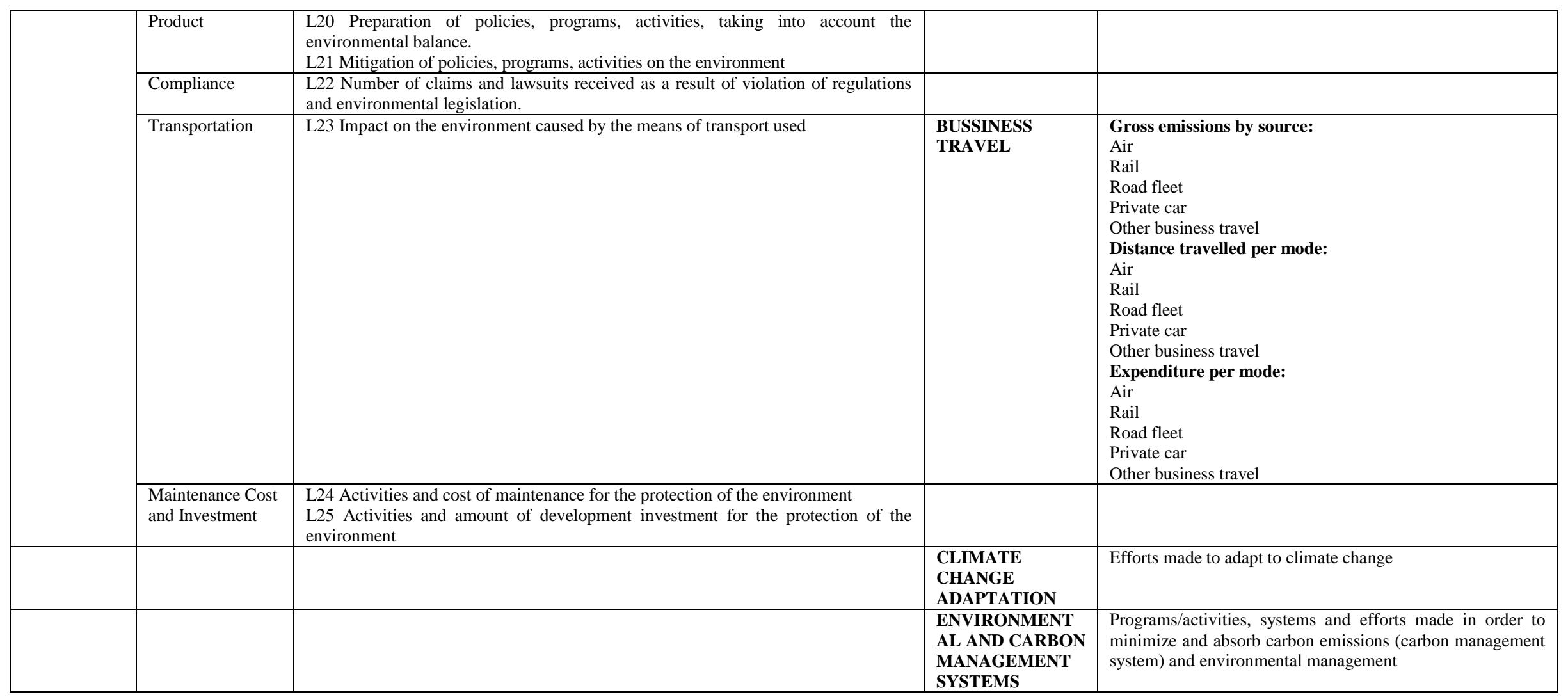

\begin{tabular}{|l|l|l|}
\hline Economy & $\begin{array}{l}\text { Economy } \\
\text { Performance; }\end{array}$ & $\begin{array}{l}\text { EK1 Proportion of direct expenditure in the APBD (Regional Budget) and its utilization in increasing the people's purchasing power } \\
\text { EK2 Amount of expenditure incurred in an effort to address the impact (either incidental or permanent) caused by climate change } \\
\text { EK3 Efforts by institutions in providing pensions for employees } \\
\text { EK4 Financial assistance received from both the central/provincial (excluding funds transfer), other local governments, other countries, or other organization }\end{array}$ \\
\hline & $\begin{array}{l}\text { EK5 Amount allocated for salaries and benefits of regional government employees } \\
\text { Economic } \\
\text { Empowerment; }\end{array}$ & $\begin{array}{l}\text { EK6 Policy and practice of local government expenditure in favor of the empowerment of local companies. } \\
\text { EK7 Expenditure proportion of APBD on local companies }\end{array}$ \\
\hline & $\begin{array}{l}\text { Economic Results } \\
\text { and Impact }\end{array}$ & $\begin{array}{l}\text { EK8 Economic benefits, outcomes and impact of investment spending } \\
\text { EK9 Local government assistance for local economy actors and the benefits for the growth of the regional economy }\end{array}$ \\
\hline
\end{tabular}

\begin{tabular}{|c|c|c|c|}
\hline Social & Labor & Employee & $\begin{array}{l}\text { LA1 Composition of employees by gender by civil servants and non-civil servants status } \\
\text { LA2 Comparison of the number of new employees with the old employees by age group and gender } \\
\text { LA3 Employee turnover rate by age group and gender }\end{array}$ \\
\hline
\end{tabular}




\begin{tabular}{|c|c|c|}
\hline & & LA4 Total salaries and other honors given to civil servants who are not given to non-civil servants \\
\hline & $\begin{array}{l}\text { Relationship between leaders } \\
\text { and subordinates }\end{array}$ & LA5 Number and percentage of permanent employees who get work protection by collective agreements \\
\hline & $\begin{array}{l}\text { Occupational Health and } \\
\text { Safety (K3) }\end{array}$ & $\begin{array}{l}\text { LA6 Security and health services provided both for civil and non-civil servants } \\
\text { LA7 Existence of a sub-unit responsible for occupational health and safety (K3) } \\
\text { LA8 Comparison of the number of employees who operate a K3 sub-unit by the total number of employees in the work unit } \\
\text { LA9 Level of occupational accidents and loss of person-days caused by accident or illness by gender } \\
\text { LA10 Education programs, training, and counseling about health and healthy behavior for employees and their families }\end{array}$ \\
\hline & Education and Training & $\begin{array}{l}\text { LA11 Hours of training on average per year per employee for both civil and non-civil servants by gender } \\
\text { LA12 training program to enhance the managerial skills as well as other specialized skills that support successful employment and career sustainability } \\
\text { LA13 Composition of employees by gender who have the opportunity to participate in training and developing career }\end{array}$ \\
\hline & Equality of Opportunity & LA14 Composition of positions in the organizational structure based on gender, class, and educational background \\
\hline $\begin{array}{l}\text { Human } \\
\text { Rights }\end{array}$ & $\begin{array}{l}\text { Investment and Procurement } \\
\text { Practices }\end{array}$ & $\begin{array}{l}\text { HR1 Consider the implementation practice of human rights by selected partners } \\
\text { HR3 Total hours of training on policies and procedures of human rights that are relevant to the activities } \\
\text { HR4 Percentage of employees who follow the training on policies and procedures of human rights that are relevant to the activities }\end{array}$ \\
\hline & Non-discrimination; & HR5 Number of complaints/lawsuits on discrimination cases on employees triggered by differences in gender and disability \\
\hline & $\begin{array}{l}\text { Prevention of Forced Labour } \\
\text { to Employees }\end{array}$ & HR7 Implementation of working days, working time, rest periods and overtime work restrictions policy for employees \\
\hline & $\begin{array}{l}\text { Human Rights Violation } \\
\text { Treatment; }\end{array}$ & $\begin{array}{l}\text { HR8 Existence of organizational personnel trained and assigned specifically to deal with cases of human rights violations in the organization } \\
\text { HR9 Number of complaints of human rights violations } \\
\text { HR10 Number of resolving cases of human rights violations through formal mechanisms }\end{array}$ \\
\hline & $\begin{array}{l}\text { Local Cultural Community } \\
\text { Rights; }\end{array}$ & HR11 Government efforts to protect the rights of the local cultural community \\
\hline & $\begin{array}{l}\text { Assessment of Potential } \\
\text { human rights violations; }\end{array}$ & HR12 Existence of an assessment of government activity that potentially violates human rights \\
\hline Society & Local Community & $\begin{array}{l}\text { SO1 Number of programs and activities that provide opportunities for the public to initiate, implement, and benefit directly } \\
\text { SO2 Activities that potentially have negative impact on society. A description of the negative impacts and benefits to society } \\
\text { SO3 Prevention and management for the public on the negative impact of the activities/programs of government }\end{array}$ \\
\hline & Corruption & $\begin{array}{l}\text { SO4 Risk analysis of likelihood of corruption in each SKPD } \\
\text { SO5 Activities/ programs conducted by the government in an effort to instill a culture of anti-corruption } \\
\text { SO6 Number of employees who participate in training on policies and procedures of anti-corruption } \\
\text { SO7 Efforts made in dealing with cases of corruption }\end{array}$ \\
\hline & Public Policy & $\begin{array}{l}\text { SO8 Community engagement efforts in formulating any public policy } \\
\text { SO9 Public education efforts made toward the public policy set } \\
\text { SO10 The handling of any public complaints against the public policy set } \\
\text { SO11 Amount of financial aid and other assistance to political parties, politicians, and NGOs in the process of setting any public policy }\end{array}$ \\
\hline & Anti Monopoly Policy & SO12 Policies to prevent monopolistic practices in creating a fair business competition behavior in society \\
\hline & Compliance & SO13 Financial and non-financial sanctions applied to people who violate the laws and regulations of local government \\
\hline
\end{tabular}




\section{B. Confirmatory Factor Analysis}

Distribution of questionnaires was conducted to simulate the validity and reliability of the indicators of each variable used in the sustainability report disclosure. In this simulation, questionnaires were distributed only to a limited circle, especially academics and graduate students of economic faculty. Two hundred sets of questionnaires were distributed and only 72 sets that were collected, meaning that the rate of return is $36 \%$. Further research are expected to be realized in order to obtain more representative results and the output can be used directly.

The method used in the analysis of these factors is the Second Order Confirmatory Factor Analysis, wherein the latent constructs in the study is a multidimensional construct [10]. The second order of latent construct of SR Disclosure was measured by 2 (two) first-order components, namely: Environment and Economy. Social component acted as a second order that was measured with three (3) components, namely: human rights, labor, and community. From the preliminary analysis, indicators for each factor were obtained as follows:

1. environment with 25 indicators;

2. economy with 9 indicators;

3. labor with 14 indicators;

4. community with 13 indicators;

5. human rights with 10 indicators.

Based on the results of the questionnaire data processing, the average score of each indicator and confirmatory factor analysis models are as follows:

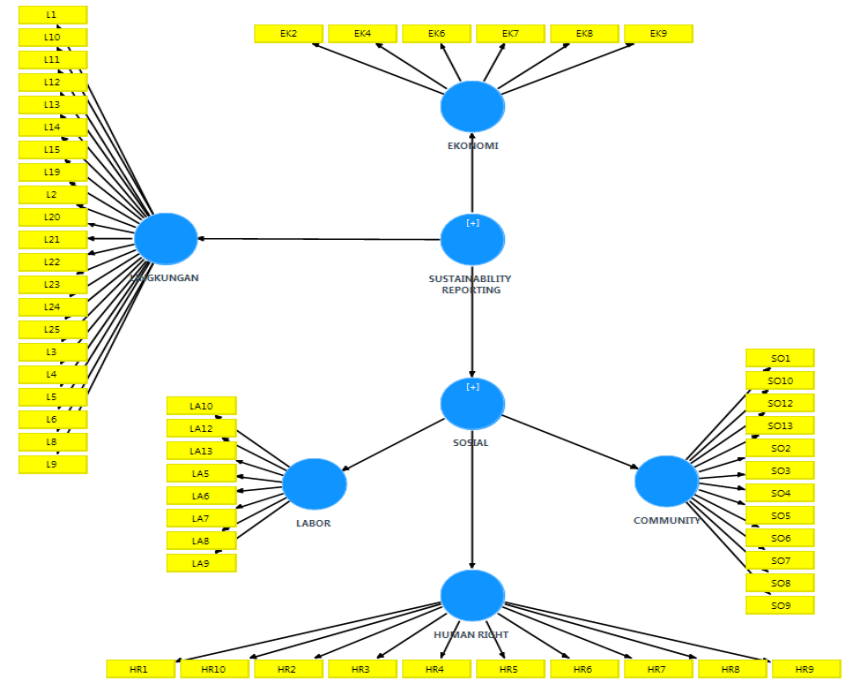

FIGURE 2: MODEL OF CONFIRMATORY FACTOR ANALYSIS

Based on the results of the processing, it can be seen that some of the indicators should be eliminated because they have a value below 0.5 , which shows the low significance of these indicators in measuring the latent variables. Indicators to be eliminated are:

a) Four indicators of Environment, namely L7, L16, L17, and L18.

b) Three indicators of Economy, namely EK1, EK3, and EK5.

c) Six indicators of Labor, namely LA1, LA2, LA3, LA4, LA11, and LA14.

d) One indicator of Community, namely SO11.

TABLE 3: COMPOSITE RELIABILITY

\begin{tabular}{l|r|} 
& Composite Reliability \\
\hline COMMUNITY & 0.903 \\
\hline EKONOMI & 0.856 \\
\hline HUMAN RIGHT & 0.929 \\
\hline LABOR & 0.829 \\
\hline LINGKUNGAN & 0.903 \\
\hline SOSIAL & 0.919 \\
\hline SUSTAINABILTTY REPORTING & 0.930 \\
\hline
\end{tabular}

TABLE 4: CRONBACHS ALPHA

\begin{tabular}{l|r} 
& Cronbachs Alpha \\
\hline COMMUNITY & 0.883 \\
\hline EKONOMI & 0.803 \\
\hline HUMAN RIGHT & 0.913 \\
\hline LABOR & 0.765 \\
\hline LINGKUNGAN & 0.889 \\
\hline SOSIAL & 0.912 \\
\hline SUSTAINABILITY REPORTING & 0.924
\end{tabular}

TABLE 5: R SQUARE

\begin{tabular}{|l|r|} 
& R Square \\
\hline COMMUNITY & 0.737 \\
\hline EKONOMI & 0.416 \\
\hline HUMAN RIGHT & 0.789 \\
\hline LABOR & 0.653 \\
\hline LINGKUNGAN & 0.608 \\
\hline SOSIAL & 0.859 \\
\hline
\end{tabular}

TABLE 6: DISCRIMINANT VALIDITY (HETEROTRAIT-MONOTRAIT RATIO)

COMMUNITY EKONOMI HUMANRIGHT LABOR LINGKUNGAN SOSIAL

\begin{tabular}{|c|c|c|c|c|c|}
\hline \multicolumn{6}{|l|}{ COMMUNITY } \\
\hline EKONOMI & 0.642 & & & & \\
\hline HUMAN RIGHT & 0.617 & 0.434 & & & \\
\hline LABOR & 0.674 & 0.305 & 0.730 & & \\
\hline LINGKUNGAN & 0.497 & 0.321 & 0.459 & 0.333 & \\
\hline SOSIAL & 0.886 & 0.479 & 0.928 & 0.961 & 0.466 \\
\hline SUSTAINABILTTY REPORTING & 0.876 & 0.657 & 0.844 & 0.780 & 0.831 \\
\hline
\end{tabular}

From Bootstrapping results above, it can be seen that all indicators used are valid and reliable to measure latent variables. It can be concluded that community, labor and human rights are significant as a second order for social latent construct. Economy and environment are significant as a second order for the disclosure of Sustainability Reporting latent constructs.

\section{CONCLUSION}

This article discloses some results that are in accordance with the objectives set at the beginning of the study, as follows: 
a) Results of the preliminary analysis (literature review) found 25 Environment indicators, 9 Economy indicators, 14 Labor indicators, 13 Community indicators, and 10 Human rights indicators.

b) Results of the preliminary questionnaire data processing (pre-survey) in the form of an analysis of the average score for each indicator and confirmatory factor analysis models, found some indicators that should be eliminated, namely: 4 Environment indicators, 3 Economy indicators, 6 Labor indicators, and 1 Community indicator.

c) The first stage of the present research outputs a Handbook of Sustainability Development Measurement through the implementation of Sustainability Reporting that is successfully compiled and further testing is needed through a pilot study method.

\section{ADVANCED RESEARCH}

The present study is a preliminary step to prepare the implementation of sustainability reporting in City/Regency Government in Indonesia. There are many things remain to be ascertained in advance so that the proposed stages can run optimally. There are several Cities/Regencies that have begun to implement some of the principles of the triple bottom line in the operations in their respective regions. This shows that the willingness of regional leaders plays a very important role in realizing the implementation of SR in the region, particularly when the law as the legal umbrella for SR is still not perfect. Result of previous research [12] also said that local government through its leader has power to embody the optimal budget and spending of government.

A pilot project needs to be implemented very soon in some Cities/Regencies to obtain a more refined model. Furthermore, the preliminary guideline that has been developed as a research outcome of this first stage research will be revised according to the results of the pilot project, so that it can be a master program for all Cities/Regencies in Indonesia.

\section{REFERENCES}

[1] John Elkington (1997). Cannibals With forks The Triple Bottom Line of Twentieth Century Business.

[2] Beria dan Aunul (2008). CSR dan Pelestraian Lingkungan Mengelola Dampak: Positif dan Negatif. Jakarta. Indonesia Business Link.

[3] Horngren, Charles T. (1993). PengantarAkuntansi Manajemen. Jilid I. EdisiKeenam. Jakarta: Erlangga

[4] Miles (2011). Embedding gender in sustainability reports. Amsterdam. Emerald.

[5] Lila Sari (2011). Implementasi Sustainability Report berdasarkan berdasarkan Global Reporting Initiative (GRI) pada PT.Telkom Indonesia Tbk (Persero) Divre V Jawa Timur.

[6] Armin, Muhammad Isra. (2011). "Pengaruh Penghargaan Indonesia Sustainability ReportingAwards (Isra) Terhadap Abnormal Return Dan Volume PerdaganganSaham (Studi Empiris Pada Perusahaan Peraih Penghargaan Isra 2009-2010)" Skripsi S1 Jurusan Akuntansi Fakultas Ekonomi Universitas Hasanuddin Makassar.

[7] Widianto, Hari Suryono (2011). "Pengaruh Profitabilitas, Likuiditas, Leverage, Aktivitas, Ukuran Perusahaan, Dan Corporate Governance Terhadap Praktik Pengungkapan Sustainability Report (Studi Pada Perusahaan - Perusahaan Yang Listed (Go-Public) Di Bursa Efek
Indonesia (Bei) Periode $2007 \quad$ - $2009 \quad$ )”. Skripsi S1 JurusanAkuntansiFakultasEkonomiUniversitasDipenogoro Semarang.

[8] Ikhsan, Arfan. (2008). Metode Penelitian Akuntansi Keperilakuan. Yogyakarta: Graha Ilmu.

[9] Nindha Utami Cahaya Muchti (2012). Pengaruh Kinerja Lingkungan dan pengungkapan Sustainability Report Terhadap Reaksi Investor (Studi Pada Perusahaan Manufaktur dan Pertambangan Yang Terdaftar di Bursa Efek Indonesia). Skripsi S1 Jurusan Akuntansi Fakultas Pendidikan Ekonomi dan Bisnis Universitas Pendidikan Indonesia.

[10] Imam Ghozali (2011). Structural Equation Modelling Metode Alternatif dengan Partial Least Square PLS. Edisi 3. Semarang: Badan Penerbit Universitas Diponegoro.

[11] Arikunto, Suharsimi. (2006). Prosedur Penelitian Suatu Pendekatan Praktik. Jakarta: Rineka Cipta

[12] Budi, Alfira dan Nelly (2011). "Optimasi Anggaran Belanja Pengelolaan Sampah Dengan Pendekatan Value for Money Dalam Era Otonomi Daerah".Hibah Bersaing Dikti. Unpublished. 